Success is far from assured - a scheduled 30 April launch had been delayed as Nature went to press, and the testing schedule of the Falcon 9 launch rocket has been accelerated to accommodate the unmanned supply flight. But if the Dragon capsule does succeed in its mission to dock with the space station and then return to Earth, NASA will be optimistic that the craft could soon carry more than supplies. With the retirement of the shuttle, the agency lost its independent link to its space station, and must now rely on the Russian Soyuz system to launch new crews and bring its astronauts home again. A contract with SpaceX to send people into space in Dragon would restore some national pride, as well as reducing crucial dependence on the production and continued success of a foreign rocket. A Soyuz failure that saw the loss of astronauts would effectively close down the space station.

The impending launch of Dragon has brought conflicting reactions. Enthusiasts see a new frontier opening up for commercial operators at all levels, from suborbital research flights to full-on private hotels in space. In a World View article on page 417, Alan Stern, an unashamed enthusiast, explains how far private firms are determined to boldly go.

Then there are the curmudgeons, those who claim that the new model is a classic case of the emperor's new clothes. NASA has always relied on private companies to build its rockets and capsules, they point out, and is handing a huge subsidy to SpaceX. So this heralded new dawn is merely a reworded contract here and a shift in financial emphasis there. The dragon, they say, has no teeth.

The truth, as so often, is likely to fall somewhere in between. Although aerospace firms such as Lockheed and Boeing have always helped NASA to carry the stars and stripes aloft, they did so on a costplus basis, with the agency meeting all costs, however large the eventual bill, and then adding on a substantial and guaranteed profit. If Dragon shows that the private sector can do more on its own terms - from design to sourcing component parts - then the costs will come down. Scientists should welcome the move. The further NASA can get from the cost-plus contracts of the past, and the nearer to buying room on a rocket as a commodity - similar to seats on a commercial airliner - the better. NASA could then spend more of its money on the things to be launched, people and probes, rather than on rocket launches that remain as expensive as they have always been.

"The great
unlinownremains
the demand
from scientists
and wealthy
individuals
willing topay to
access space."

And as the News story on page 426 shows, the planned launch of Dragon - and its ability to bring back scientific samples under controlled conditions - is already raising hopes in the space-science community that the space station could finally begin to fulfil its potential for research.

There is strong precedent for the way the US government is trying to nurture the commercial space-flight business. In the early days of aeroplane flight, government officials handed out guaranteed contracts to aviation pioneers for carrying airmail. And in the 1970s, by both funding the developers of microchips and promising to buy the results, the US Department of Defense kick-started the computer industry.

The market for the services provided by SpaceX and its ilk is, of course, smaller. The space station is scheduled to operate - and so will need to be supplied - until only 2020. Contracts to launch satellites are lucrative, but the great unknown on the balance sheet remains the demand from scientists and from wealthy individuals willing to pay big money for tourist flights to space.

A successful SpaceX operation next month will not resolve such questions, but it would make more people ask them more seriously. And that can only be a good thing.

\section{Suckers for success}

\section{The use of leeches is making a comeback, and not just in medicine.}

I n the 1807 poem Resolution and Independence, William Wordsworth recalls a dawn encounter with a withered old man on a moor: "He told, that to these waters he had come | To gather leeches, being old and poor: |Employment hazardous and wearisome!"

Nineteenth-century gatherers often dunked their legs into leechfilled bogs and ponds until the bloodsuckers began to feast. The motivation was money: medical use of leeches, or hirudotherapy, was at its height in Europe, and surgeons needed every leech they could get. France reportedly imported 42 million medicinal leeches in 1833 alone.

Leech therapy dates to ancient Greece, and perhaps earlier. Hippocrates preached the importance of balancing the four humours (blood, phlegm and black and yellow bile) through bloodletting. Because they secrete a host of enzymes to anaesthetize their victims at the spot of a bite and to keep the blood flowing, leeches were useful when drawing blood from sensitive parts of the body such as the mouth, larynx and anus.

Nicander of Colophon, who lived in the second century BC, described the medical use of leeches, which belong to the same phylum (Annelida) as earthworms, in his poem Alexipharmaca. Greek, Roman and Arabic doctors embraced their use, and English doctors in the Middle Ages were often called leeches; the Anglo-Saxon word loece means healer.

The leech bubble burst in the second half of the nineteenth century, when people realized that the animals made most patients worse, not better. By 1879, London's leading leech importer was distributing just a tenth of the 30,000 or so it once had, and they "principally go to Scotland", the British Medical Journal noted that year.
Still, the leech has never really left the medical mind, and it is starting to be used again. Reconstructive surgery, always a hotbed of innovation, was the first field to re-embrace the medicinal leech (Hirudo spp.). A survey of the 62 plastic-surgery units in the United Kingdom and Republic of Ireland in 2002 found that $80 \%$ had used leeches in the past five years, with just four centres reporting that a patient had turned down hirudotherapy (I. S. Whitakera et al. Br. J. Plast. Surg. 57, 348-353; 2004). No wonder. Leeches are thought to improve the outcomes of reattached digits, ears and other body parts by preventing veins from becoming clogged .

Leeches also ease the pain caused by osteoarthritis. Among the 30 or so biologically active substances in their saliva are molecules that stop inflammation and blood clotting, both of which are involved in arthritis.

Medical-grade-leech sales haven't returned to their early-nineteenthcentury heights, but the animals are once again selling briskly. Britain's largest supplier, Biopharm Leeches in Hendy, Wales (which has the tag line "The biting edge of science"), ships around 50,000 per year, and in 2004, a French firm, Ricarimpex in Eysines, won clearance from the US Food and Drug Administration to market its leeches as medical devices in the United States.

Leech use is not restricted to medicine. As we report on page 424, tropical leeches are being recruited in the search for endangered species. These leeches preserve DNA from the last mammal they fed on, so can offer clues to the mammal's range and location. Conservationists in Vietnam and Laos plan to scour the bellies of leeches in their search for the saola antelope (Pseudoryx nghetinhensis), one of the world's rarest animals.

It is a fitting twist for the medical leech, which itself is listed as a 'near threatened' species in the wild and may have been in decline $\rightarrow$ NATURE.COM To comment online, click on Editorials at: go.nature.com/xhunqv even in Wordsworth's time. "Once I could meet with them on every side," the old leech gatherer tells the young poet. "But they have dwindled long by slow decay; | Yet still I persevere, and find them where I may." - 